\title{
Modern Solutions of Hippocratic "Equation" (on the Relations of Medicine and Philosophy)
}

\author{
Olga F. Neskriabina* \\ Siberian Federal University \\ 79 Svobodny, Krasnoyarsk, 660041, Russia
}

Received 24.03.2015, received in revised form 17.04.2015, accepted 12.08.2015

\begin{abstract}
Despite the abundance of assurances in striving for the unity of philosophy and medicine, their actual relations are far from being friendly.

Other than an objective barrier to mutual understanding (the level of medicine is empirical and theoretical, the level of philosophy is meta-theoretical) there are also the reasons which are not so thorough and, thus, can basically be eliminated. One of them is the assumptions which are insufficiently substantiated and thus should not be necessarily adhered to, especially when modern philosophy suggests a better solution.

Owing to a high degree of generality, methodological (philosophical) grounds or principles are individualized and filled with specific meanings. Therefore, basing on a general philosophical reason, scholars often come to different theoretical conclusions.

Multi-valued philosophical structures (such as dialectics) lead to a feeling of basing on some of the principles with the possibility of their different application.

Philosophical methodology plays an important role in the process of cognition, the role being psychological rather than methodological. It provides cognitive confidence, thereby increasing motivation to creativity. In its methodological function philosophy implicitly comprises an aesthetic component.

In the set of philosophical issues of biology and medicine there are both traditional and relatively new ones. Due to the progress of humanities and elimination of ideological attitudes, the relations of biological and social in a human have clarified. With regard to the issue of the relations between science and mythology there is no tangible progress in its decision.

The "agenda" of philosophical discourse is formed in the process of the medical community's awareness of challenges that science and practice face. Methodological problematics is currently presented by the conception of evidence based medicine drawn towards the ideal of classical rationality. The scope of ontological and axiological (bioethical) problematics has been enlarged by the issue of pathogenicity of media environment and information security.
\end{abstract}

Keywords: philosophy, medicine, methodology, discourse, rationality, scientific paradigm.

DOI: 10.17516/1997-1370-2015-8-9-1847-1854.

The article provides the author's point of view which might be disagreed with by some of the colleagues.

Research area: philosophy.

(C) Siberian Federal University. All rights reserved

* Corresponding author E-mail address: nescr@mail.ru 


\section{The problem}

The discussion of the relations between philosophy and medicine is rarely complete without repeating Hippocrates' famous words: "A physician philosopher is equal to God". This formula usually contains the idea of medicine and philosophy unity. However, it may also suggest a hint at the unattainable ideal.

The immediate reason for the discussion of the issue of the relation of philosophy and medicine is the need to improve the process of postgraduate medical education, "History and philosophy of science" exam being its part. The experience of work with postgraduate students and applicants for the degree shows that some topics of the "Philosophy of science" course are understood markedly worse than the rest. Based on the well-known patterns of the psyche, it can be assumed that the reason is the resistance: information that is not built in cognitive representations is poorly remembered.

This article is aimed to analyze the causes and conditions of the reduction of cognitive dissonance between philosophical and medical discourse. The object of the research is a philosophical aspect of the "philosophy medicine" opposition.

We assume that there are difficulties in the way of mutual understanding. They are of two kinds. The first ones are basically eliminable. They are associated with the current state of philosophical discourse. Other difficulties lie in insurmountable difference in cognitive styles of theoretical and practical (clinical in this case) thinking. It should be noted that the eternal reasons of disagreement should not be dramatized as there is no complete harmony in much simpler situations. Moreover, it is useful: contradiction motivates theoretical search because we always need contradiction to eliminate it.

\section{On the subject and object of philosophical discourse}

Complex nature of mutual understanding is fared from some mental traditions. Academic literature on philosophy of science contains traditional assumptions dating back to the last century and having no convincing arguments to support them. The necessity of learning them reduces modern physicians' concept of philosophy. In our view, the idea of philosophy as knowledge of the most general laws of being should be considered outdated. This interpretation diminishes the scope of philosophical discourse. From the point of formal logic it makes such phrases as "philosophy of medicine", "philosophy of technology", "philosophy of language", etc. contradictory.

The concept of "philosophy" can be defined by specifying its specific features which distinguish philosophical discourse. These are gravity of the problem and thoroughness of its consideration, criticality and reflexivity, validity and beauty of thought, axiological nature.

Features of philosophic thinking are inherent to all types of theoretical discourse. Thus, philosophy is not some special area of knowledge existing along with the other ones although there exists a separate "professional philosophy'.

Nowadays familiarity with philosophy also begins with the establishment of its special status. The word "philosophy" is associated with the profession and all social institutions that accompany any profession. This view prevents actualization of the other point of philosophy, which is the main one, in my opinion. It runs that every science with a theoretical base includes philosophy as its part. Philosophical cognition has its specificity, being inside certain sciences. Accordingly, the subject of philosophical thinking is professionals in their particular area knowledge (physicists, biologists, physicians, etc.). 
This understanding of the scope philosophy does not mean that its esoteric modes of existence are put a veto on. Just as there is "art for art" apart from art for the public, so there is also "philosophy for philosophy". These two spiritual practices are necessary to maintain a high level of professionalism.

The course of philosophy has a wellestablished assumption that the process of separation of science from philosophy takes place in the course of history. This tradition can also cause mental confusion. In fact, if sciences drop out of philosophy it must mean that they further develop on their own. It has become the custom that Newton and Laplace as well as Bohr, Einstein, Dostoyevsky, and Pavlov are not called philosophers, while Descartes, Leibniz, and Kant are not called scientists.

The "separation" formula grossly oversimplifies a real historical process of knowledge differentiation. It does not reflect the difference between the empirical and theoretical levels that is innate of cognition. With regard to medicine, it is the maxim of Hippocrates that is about synthesis of philosophy and medicine but not about separation. Pythagoras is a mathematician, Hippocrates is a physician, and Socrates is a social thinker. Knowledge differentiation is its ancient natural dynamic state. As for the system of knowledge, according to Aristotle, philosophy can be thought to be separated from scientific knowledge but not vice versa. General patterns of differentiation processes are rather conventional. They are tied to specific cultural traditions and dependent on historically volatile meanings of the concepts of "science", "philosophy", "subject of philosophy", etc.

\section{Methodological function of philosophy}

The thesis of methodological function of philosophy, which is a key assumption of the "History and philosophy of science" course, is one of the most challenging in terms of cognitive comprehension.

The issue of the role of philosophical methodology is complex by its very nature. However, a large part of this complexity, in our opinion, is explained by the "unnecessary multiplication of entities". The dialecticalmaterialist philosophy distinguishes between ideals and norms of science, philosophical foundations of science, philosophicalmethodology and scientific methods. This distinction can still be found in Russian literature. The latter includes the systemic approach, information approach, etc. (Istoriia i filosofiia nauki 2010: 119-122). Such a distinction is not sufficiently justified conceptually as well as pragmatically. It creates unnecessary barriers to the agreement between abstract-and-theoretical and specific scientific levels of cognition. It should be noted that the philosophy of dialectical materialism has serious merits in the development of the criteria of scientific content, principles of objective cognition, etc. However, for obvious reasons it suffered from ideological "xenophobia", which could not but affect the discussion of the problem of the philosophical method.

Regarding methodological principles, one textbook runs: "Their application provides a correct dialectical-materialist approach to understanding the laws of general pathology and right orientation in the countless particulars of human pathology" (Mikhailov 2007, p. 13). Such certain, almost categorical statements about the role of philosophical methodology create the effect of unrealistic expectations.

The main feature of diamat approach is apparently in literal understanding of philosophical methodology as a method of obtaining new knowledge by applying the maxim of materialism and categories of dialectics. It was assumed (though not expressed explicitly) that philosophical methodology works on the 
principle of deductive inference, although another epistemological status of deduction was established in logic long ago. A specific feature of deductive reasoning is the absence of heuristic potential. Consequently, application of philosophical concepts is valuable for medical knowledge justification and systematization, but not new knowledge formulation.

General concepts are implicitly individualized, as humans interpret the same terms differently. Thus, each time some semantic guidance is needed. This partly explains the abundance of discourse on the meaning of philosophical concepts. Practice leads to the development of specific sets of images of scientific concepts in the minds of specialists in different areas of medical knowledge, thus complicating philosophical discourse in diversified audience.

Einstein and Bohr's controversy on classical determinism is a significant fact in the history of philosophy of science. They drew different philosophical conclusions from the same theoretical assumptions and stuck to their own programs. This implies that different philosophical comprehension is formed on the same information base, and vice versa, one philosophical idea can lead to different theoretical conclusions. This feature is able to throw doubt upon heuristic value of philosophy. However, the process of cognition does not come to the activity in rational sphere exclusively. Motivation of creativity and emotional sphere are also important. One should not underestimate the aesthetic and communicative functions of philosophy.

A reservation should be made here: different humans have different need for philosophical discourse. Not all the scientists are capable of philosophical thinking that does not diminish their intellectual merits and abilities for scientific work. Love or dislike for theorizing depends on many factors, scientific specialty, mentality of a particular professional group, and probably the experience of studying philosophy at a university being some of them. Individual cognitive style, belonging to artistic or thinking type, etc. presumably play an important role.

Due to their high degree of abstraction general scientific methodological principles are not permissive but forbidding as they exclude modes of mental and practical activity non-compatible with them but do not specify particular solutions. Thus, due to its semantic ambiguity the thesis of dialectical unity of structure and function does not provide specific solutions to the issue of the principles of brain organization of higher mental functions.

Modern educational (and other) literature identifies philosophical methodology with dialectics. There is still a sign of progressive development in dialectization of science (Khrustalev 2005, p. 187). However, in our opinion, there are reasons for significantly different understanding of the situation in the system of "philosophy - methodology of science dialectics" relations.

Scientific and artistic communities need concepts that, on the one hand, would give a feeling of support on certain standards and principles, and, on the other hand, would not enchain the freedom of thought. Dialectics provide explanation for any assumption. Since the work at the theory is usually a long and arduous process a scientist needs support in the form of general ideas, giving confidence in the correctness of the path chosen. It is clear that not everyone needs support, and a different system can be applied instead if it is sufficiently common and, consequently, has semantic "capacity". These are, for example, phenomenology, methodology of research programmes, systemic analysis, etc. As for many prominent scientists, they formulate their own methodological principles of the philosophical level. 
A heuristic role of dialectics depends on the status of the hypothesis supported by dialectics. If the hypothesis is correct dialectics helps in establishment the truth and if it is not true it helps to become firmly convinced in one's delusion. This conclusion is consistent with historical facts: dialectical materialism has been applied not once nor twice to support erroneous ideas and combat true ones.

Dialectics is an example of a closed system in the sense that an erroneous conclusion based on its arguments can be interpreted as the lack of dialectical thinking. According to logic, the amazing resourcefulness of dialectics is its vulnerable point but it explains its attractiveness from the perspective of psychology of cognition.

\section{Scientific paradigm and neo-mysticism}

According to the author, all mentioned above should become a prelude to the discussion of modern philosophical problems of biology and medicine. One of them is attitude to mysticism and parascience, an eternal companion of cognition. It is worth noting that the problem is not only how to combat it but also whether it should be done. In Soviet times this issue did not exist. Struggle with overseas and home-grown mysticism was probably the main task of philosophy. Prominent scientists, journalists and cultural figures took part in scientific apologia. As for the canons of science, in the late-Soviet period they were generally observed (after the scandals with genetics and cybernetics). In the field of sociohumanitarian knowledge they were declared, at least.

In the post-Soviet period the situation changed. People gained the impression that science does not lay a claim to the truth and that they actually lost the idea of what the truth is. The media greatly contributed to the fact that the average man has no idea of where the line between science and mysticism is.
Answering the question whether mysticism should be fought with, its genetic and semantic kinship with the religious worldview both on doctrinal and psychological (emotional) levels should be kept in mind. And this complicates the situation. Unlike in Soviet times, not many scientists currently believe that religion is harmful to human health. If we consider the following connection: the health of the organism largely depends on the mental state, and the latter implies faith and hope for a higher power, then the answer to the question about the role of mysticism becomes not obvious. At the same time the medical community's concern with the dominance of wizards, psychics, etc. is quite clear and well-grounded.

In my opinion, mysticism of the highest order, and namely traditional religions (Christianity, Islam) should be opposed to home-grown mysticism. There is the centuries-old endured experience of faith and knowledge coexistence in these religions. Despite the above-mentioned kinship between religion and mysticism this relationship can and should be weakened if it is propagandized from both sides. These are discourse on the difference between faith and superstition and discourse on their contradiction but not inconsistency of scientific and religious worldviews. Attacks on science in the name of religion should be opposed to. The media often voice the idea of conflict between modern medicine and church. Some representatives of the clergy support it. This results in the advantageous position of "quasi" science and "quasi" religion.

Saying that the medical profession obliges to stick to scientific paradigm, it should be born in mind that two philosophies can go together in one subject. In his / her professional activities the doctor can think and act from the position of scientific rationality and exhibit a tendency to irrationalism in other modes of life. Spatiotemporal and semantic separation of these life- 
worlds apparently make it possible to put up with mental mismatch.

\section{Current philosophical problems of biology and medicine}

"The doctor philosopher is equal to God"... Basing on the conceptual but not the verbal meaning of the sentence, it should be interpreted as "The doctor scientist is equal to God". The inquiry for a philosophical problematics is formed in the bowels of specific scientific knowledge. There is no point in a big fuss about confrontation of nosologism and antinosologism if the medical community is not interested in it.

The structure of biomedical philosophical problematics can be represented by three relatively separate units: (1) ontological, (2) methodological (epistemological) and (3) axiological problems ${ }^{2}$.

The central position in ontological module is still taken by closely related issues of biosocial unity and the psycho-physiological problem. There is a big progress in current development of these issues. It results from comprehension of specific scientific knowledge achievements. Philosophy has overcome the antinomy engendered by ideological bias. The postulate of monism, that has been suggested by philosophy for a long time (but without sufficient justification), made it impossible to notice the diversity of relations in complex objects. At present methodology of the systemic approach, and the conception of the organic system in particular, admits diversity of ways of biosocial unity organization. It might be said that modern approaches to the problem of human nature and consciousness corresponds to the style of medical thinking to a greater extent.

A set of methodological problems is presented by "evidence based medicine". This conception accumulates the main issues of medical discourse: peculiarities of clinical thinking, principles of assessing the diagnostic methods effectiveness, ways of making decisions on clinical interventions, etc. (Grinkhal'kh 2006; Kotel'nikov, Shpigel' 2000).

Recently the idea of historically successive three types of scientific rationality - classical, nonclassical and post-nonclassical - has become popular in textbooks for the "History and philosophy of science" course (Stepin 2006; Filosofiia nauki 2006; Mineev 2008; Chernikova 2011). The focus is given to the moment of succession, to the idea that "subsequent stages do not reject the previous ones" (Stepin 2006, p. 328) but not to distinguishing features of these stages. This is especially true with regard to medicine. In our view, the ideal of the "evidence based medicine" concept is classical rationality mainly. "The classic type of scientific rationality, focusing on the object, aims at the elimination of everything that relates to the subject, means and operations of its activities via theoretical explanation and description" (Stepin 2006, p. 326).

Axiological problematics of biomedical knowledge is discussed in the framework of bioethical research. The issue of information-andpsychological security is foregrounded within axiological problems due to the information boom. One of the social hygiene tasks is struggle for emotional purity of media sphere the medical community can participate in both as a professional expert, a customer and a media product creator. Interactive nature of media sphere provides rich opportunities for these forms of participation.

\section{Conclusion}

Certain stereotypes concerning the subject and scope of philosophy must be overcome for harmonization of the relations between medicine and philosophy. Philosophy should be associated with the specific features of philosophical discourse but not with institutions.

Methodological function of philosophy is in activating creativity, harmonization of cognitive 
sphere. Dialectics affects the process of cognition not so much as a method of thinking but as an element of the psychology of creativity if a scientist feels trust towards its principles.

Development of science leads to a new approach to the solution of philosophical issues of biology and medicine which arise and are formulated in the system of medical and biological knowledge.

Problematics of the philosophical level includes ontological, methodological, and axiological issues. The spirit of the times in the field of ontology and axiology is in the attention to the issue of media environment pathogenicity and information security.

Methodological topics are currently developed within the conception of evidence based medicine. In our opinion, this conception demonstrates the intention and movement of medical knowledge to the ideal of classical rationality.

\footnotetext{
1 Interestingly, in his "Ludwig Feuerbach and the end of classical German philosophy", the former main source to study dialectical materialism, F. Engels wrote that the need for professional philosophy will die off when the dialectical method wins in science. This F. Engels' idea has never been popular, at least in the printed texts. In contrast, in Soviet times professional philosophy made many efforts to prove specificity of philosophical cognition.

2 This classification is arbitrary as the ontological problem of biosocial unity can be considered in methodological and axiological aspects.
}

\section{References}

1. Bel'skaia E.Iu., et al. Istoriia i filosofiia nauki (Filosofiia nauki) [History and philosophy of science (Philosophy of science)]. Moscow: Al'fa-M: INFRA-M, 2010.

2. Chernikova I.V. Filosofia $i$ istoriia nauki [Philosophy and history of science]. Tomsk: Izdatel'stvo NTL, 2011.

3. Filosofiia nauki [Philosophy of science]. Ed. by S.A. Lebedev. Moscow: Academic project, 2006.

4. Grinkhal'kh T. Osnovy dokazatel'noi meditsiny [Evidence based medicine]. Moscow: “GEOTAR-Media”, 2006.

5. Khrustalev Iu.M., Tsaregorodtsev G.I. Filosofiia nauki i meditsiny [Philosophy of science and medicine]. Moscow: "GEOTAR-Media”, 2005.

6. Kotel'nikov G.P., Shpigel' A.S. Dokazatel'naia meditsina. Nauchno-obosnovannaia meditsinskaia praktika [Evidence based medicine. Scientifically based medical practice]. Samara: Samara State Medical University, 2000.

7. Maksimov A.G. Dokazatel'naia meditsina [Evidence based medicine]. St.-Petersburg, 2001.

8. Mikhailov V.P. Obshchaia patologiia [General pathology]. Rostov-on-Don: Phoenix, 2007.

9. Mineev V.V. Vvedenie $v$ istoriiu i filosofiu nauki [Introduction to history and philosophy of science]. Krasnoyarsk: Krasnoyarsk State Pedagogical University named after V.P. Astaf'ev, 2008.

10. Shevchenko Iu.L. Filosofiia meditsiny [Philosophy of medicine]. Moscow: GEOTAR MED, 2004.

11. Stepin V.S. Filosofiia nauki. Obshchie problemy [Philosophy of science. General issues]. Moscow: Gardariki, 2006. 


\title{
Современные решения «уравнения» Гиппократа (Об отношениях медицины и философии)
}

\author{
О.Ф. Нескрябина \\ Сибирский федеральный университет \\ Россия, 660041, Красноярск, пр. Свободный, 79
}

\begin{abstract}
Несмотря на обилие заверений в стремлении $к$ единству философии и медицины, действительные отношения в данной паре не столь дружественны.

Помимо объективного барьера на пути взаимопонимания - медицина - эмпирический и теоретический уровень, философия - метатеоретический - существуют причины не столь основательные и, в принципе, устранимые. Одна из них - наличие недостаточно обоснованных положений, придерживаться которых нет необходимости, поскольку в современной философии найдены более точные решения.

В силу высокой степени общности методологические (философские) основания или приниипь индивидуализируются, наполняются особенными смыслами. Поэтому, исходя из единых философских оснований, ученые зачастую приходят к разным теоретическим выводам.

Многозначные философские конструкиии (такие как диалектика) дают ощущение опоры на некие принципы, оставляя возможность их различного применения.

Философская методология играет важную роль в процессе познания, но не столько собственно методологическую, сколько психологическую. Она дает когнитивную уверенность, усиливая тем самым мотивацию творчества. В методологической функиии философии имплицитно присутствует эстетическая компонента.

В комплексе философских проблем биологии и медицины есть традиционные и относительно новые темы. Благодаря прогрессу наук о человеке и элиминации идеологической установки прояснились взаимосвязи биологического и сочиального в человеке. Что касается проблемь отношений между наукой и мифологией, то в ее решении нет ощутимых сдвигов.

«Повестка дня» философского дискурса формируется в проиессе осознания медицинским сообществом задач, стоящих перед наукой и практикой. $B$ настоящее время методологическая проблематика представлена концепцией доказательной медицины, тяготеющей $\kappa$ идеалу классической раџиональности. $K$ комплексу онтологической и аксиологической (биоэтической) проблематики прибавилась тема патогенности медиасреды и обеспечения информачионной безопасности.
\end{abstract}

Ключевые слова: философия, медицина, методология, дискурс, рациональность, научная парадигма.

В данной статье автор выражает собственную точку зрения, с которой могут не согласиться некоторые его коллеги.

Научная специальность: 09.00.00 - философские науки. 